\title{
BLOOD GAS AND pH STUDIES DURING USE OF THE CARLENS CATHETER*
}

\author{
SaIt Tarhan, M.D., aNd Ruchard O. Lundborg, M.D.
}

The Carlens endobronchial Catheter was first used during anaesthesia for thoracic surgery by Björk and Carlens ${ }^{1}$ in 1950 to prevent the spread of secretions from one lung to the other during pulmonary resection. The routine use of the Carlens catheter for airway control during thoracic surgery has been recommended $^{2,3}$ for that reason and for the additional advantages of wider surgical exposure, minimal lung retraction, and assurance of adequate ventilation via one bronchus during suctioning or surgical manipulation of the other. ${ }^{2,4}$

Since the intentional collapse of one lung is often part of the technique of using this catheter, significant arterial oxyhaemoglobin desaturation may occur if there is a large pulmonary blood flow to the nonventilated lung. ${ }^{2,4-9}$ This flow through the collapsed lung theoretically could be increased if a high airway pressure were maintained, thus causing an increased resistance to pulmonary blood flow in the ventilated dependent lung. ${ }^{10}$ Venous admixture in the ventilated dependent lung also may occur, particularly if regions of atelectasis are present. ${ }^{5}$ If significant, the arterial desaturation may jeopardize oxygenation of cerebral tissue and other vital organs. ${ }^{5}$

It was our intention to explore these mechanisms of intrapulmonary shunting by measuring arterial oxygen and carbon dioxide tensions and $\mathrm{pH}$ during various periods of thoracotomy, using three different anaesthetic mixtures. The mixtures were 0.5 to 1 per cent halothane with $\mathrm{N}_{2} \mathrm{O}-\mathrm{O}_{2}(60: 40), \mathrm{N}_{2} \mathrm{O}-\mathrm{O}_{2}(50: 50)$, or $\mathrm{O}_{2}(100 \%)$.

\section{Materials and Procedure}

Ten patients were studied: five had pneumonectomy, one lobectomy, three wedge resection, and one repair of a diaphragmatic hernia. Their ages ranged from 35 to 72 years. Total anaesthesia time varied from 80 to 260 minutes. All patients were premedicated with 6 to $8 \mathrm{mg}$. of morphine sulphate, $0.4 \mathrm{mg}$. of atropine sulphate, and $100 \mathrm{mg}$. of sodium pentobarbital. Sodium thiopental (250 to $325 \mathrm{mg}$.) was administered for induction, after which 60 to $80 \mathrm{mg}$. of succinylcholine was given for intubation with the Carlens catheter. All patients had manually controlled ventilation with a gas flow of $5 \mathrm{~L}$. through a semiclosed circle system with carbon dioxide absorption, and intermittent hyperinflations. Minute ventilation was adjusted as necessary to prevent retention of carbon dioxide. All patients were in the lateral position except for one patient in the

'Mayo Clinic and Mayo Foundation: Section of Anesthesiology, Rochester, Minnesota. Read at the Annual Meeting of the Canadian Anaesthetists' Society, Montebello, Quebec, May 12 to 16,1968 .

Can. Anaes. Soc. J., vol. 15, no. 5, September 1968 
semilateral position. During anaesthesia, a drip of 0.2 per cent succinylcholine was used intermittently as needed. The total dose of succinylcholine, including the amount given for intubation, ranged from 180 to $520 \mathrm{mg}$. The first blood sample was obtained from the femoral artery, the remainder through a no. 16 plastic needle in the radial artery. Determinations of $\mathrm{Pa}_{\mathrm{O}_{2}}, \mathrm{~Pa}_{\mathrm{CO}_{2}}$, and $\mathrm{pH}$ were made by appropriate electrodes (Instrumentation Laboratory, Boston, Mass.) maintained at $37^{\circ} \mathrm{C}$. Microhaematocrit determinations were obtained from each blood sample. Buffer-base values were determined from the nomogram of Singer and Hastings. ${ }^{11}$

Blood samples were taken in the following order:

1. The first sample was taken from the awake patient, breathing air.

2. The second sample was taken after ten minutes of breathing nitrous oxide and oxygen (60:40) with 1 per cent halothane.

3. The third sample was obtained shortly after the pleural cavity was entered.

4. The fourth sample was taken after the chest had been open for ten minutes.

5. The fifth sample was drawn ten minutes after the nondependent lung had been allowed to collapse.

6. The sixth sample was obtained after the dependent lung had been ventilated for ten minutes with a mixture of nitrous oxide and oxygen (50:50) and 1 per cent halothane.

7. The seventh sample was taken after the dependent lung had been ventilated with 100 per cent oxygen and 1 per cent halothane for ten minutes.

8. The eighth sample was taken three to five minutes after the pulmonary artery was clamped in those patients undergoing pneumonectomy.

9. The ninth sample was drawn after surgery with the patient awake, and having breathed air for at least ten minutes.

\section{RESULTS}

\section{Oxygen}

If a $\mathrm{Pa}_{\mathrm{O}_{2}}$ of $70 \mathrm{~mm}$. $\mathrm{Hg}$ or higher is considered acceptable, ${ }^{7}$ all $\mathrm{Pa}_{\mathrm{O}_{2}}$ determinations obtained prior to the deflation of one lung (samples 1 through 4) are satisfactory (Table I).

Ten minutes after the nondependent lung had been allowed to collapse, the $\mathrm{Pa}_{\mathrm{O}_{2}}$ (sample 5) ranged from 43 to $103 \mathrm{~mm}$. $\mathrm{Hg}$, with a mean of $76 \mathrm{~mm}$. $\mathrm{Hg}$. However, four of the ten patients had a $\mathrm{Pa}_{2}$ less than $70 \mathrm{~mm}$. $\mathrm{Hg}$.

In nine patients (sample 6) with the $\mathrm{F}_{\mathrm{O}_{2}}$ increased to 0.5 , the mean $\mathrm{Pa}_{\mathrm{O}_{2}}$ increased to $122 \mathrm{~mm}$. $\mathrm{Hg}$; however, two patients still had a $\mathrm{Pa}_{\mathrm{O}_{2}}$ less than 70 $\mathrm{mm}$. $\mathrm{Hg}$ ( 55 and $69 \mathrm{~mm}$. $\mathrm{Hg}$ ).

Arterial samples (sample 7) were taken in eight patients while breathing 100 per cent oxygen and halothane (0.5 to $1 \%$ ). The mean $\mathrm{Pa}_{\mathrm{O}_{2}}$ increased to 194 $\mathrm{mm}$. $\mathrm{Hg}$, with a range of 59 to $307 \mathrm{~mm}$. $\mathrm{Hg}$. Two patients had levels of 59 and $63 \mathrm{~mm}$. Hg respectively.

The five patients undergoing pneumonectomy had arterial samples (sample 8) taken three to five minutes after the pulmonary artery was clamped. The mean $\mathrm{Pa}_{\mathrm{O}_{2}}$ increased to $393 \mathrm{~mm}$. $\mathrm{Hg}$. The patient with a $\mathrm{Pa}_{\mathrm{O}_{2}}$ of $63 \mathrm{~mm}$. $\mathrm{Hg}$ during the 
TABLE I

$\mathrm{Pa}_{\mathrm{O}_{2}}$ During Thoracotomy with Use of the Carlens Catheter

\begin{tabular}{|c|c|c|c|c|c|}
\hline \multirow{2}{*}{$\begin{array}{c}\text { Arterial } \\
\text { sample }\end{array}$} & \multirow{2}{*}{$\begin{array}{c}\text { No. of } \\
\text { patients }\end{array}$} & \multirow[b]{2}{*}{ Condition } & \multirow[b]{2}{*}{$\mathrm{FI}_{\mathrm{O}_{2}}$} & \multicolumn{2}{|c|}{$\mathrm{PaO}_{2}$} \\
\hline & & & & mean & range \\
\hline 1 & 8 & before induction of anaesthesia & 0.2 & 79 & $72-98$ \\
\hline 2 & 10 & $\begin{array}{l}\text { after } 10 \mathrm{~min} \text {. of anaesthesia; } \\
\text { lateral position }\end{array}$ & 0.4 & 161 & $131-186$ \\
\hline 3 & 10 & $\begin{array}{l}\text { shortly after pleural cavity } \\
\text { entered }\end{array}$ & 0.4 & 135 & $80-193$ \\
\hline 4 & 7 & ten min. after pleural cavity & & & \\
\hline 5 & 10 & entered & 0.4 & 107 & $85-134$ \\
\hline & & non-dependent lung & 0.4 & 76 & $43-103$ \\
\hline 6 & 9 & $\begin{array}{l}\text { ten min. after } \mathrm{FI}_{\mathrm{O}_{2}} \text { increased; } \\
\text { lung still collapsed }\end{array}$ & 0.5 & 122 & $55-215$ \\
\hline 7 & 8 & $\begin{array}{l}\text { ten min. after } \mathrm{FI}_{2} \text { increased; } \\
\text { lung still collapsed }\end{array}$ & 1.0 & 194 & $59-307$ \\
\hline 8 & 5 & $\begin{array}{l}\text { shortly after pulmonary artery } \\
\text { clamped }\end{array}$ & 1.0 & 393 & $216-479$ \\
\hline 9 & 10 & $\begin{array}{l}\text { after ten min. of breathing } \\
\text { air: patient awake }\end{array}$ & 0.2 & 66 & $50-80$ \\
\hline
\end{tabular}

previous sampling period was now found to have a $\mathrm{Pa}_{\mathrm{O}_{2}}$ of $216 \mathrm{~mm}$. $\mathrm{Hg}$. This was not the largest increase; one patient had an increase of $172 \mathrm{~mm} . \mathrm{Hg}$, from 307 to $479 \mathrm{~mm}$. Hg.

After extubation, with the patient awake and breathing air for at least ten minutes (sample 9), the mean $\mathrm{Pa}_{\mathrm{O}_{2}}$ was $66 \mathrm{~mm}$. $\mathrm{Hg}$ (range 50 to $80 \mathrm{~mm}$. $\mathrm{Hg}$ ).

Comparison of the mean $\mathrm{Pa}_{\mathrm{O}_{2}}$ for the group undergoing pneumonectomy and lobectomy (six patients) with the remaining four patients revealed a significantly $(p<0.05)$ higher mean $\mathrm{Pa}_{\mathrm{O}_{2}}$ for the former group during sampling period 5 . The mean $\mathrm{Pa}_{\mathrm{O}_{2}}$ values were 86 to 60 , respectively.

\section{Acid-Base (Table II)}

Before the operation, seven of the eight patients sampled (sample 1) had normal $\mathrm{pH}$ and $\mathrm{Pa}_{\mathrm{CO}_{2}}$. The remaining patient had a $\mathrm{pH}$ of 7.28, a $\mathrm{Pa}_{\mathrm{CO}_{2}}$ of $36 \mathrm{~mm} . \mathrm{Hg}$, and a buffer-base value of $40 \mathrm{mEq} . / \mathrm{L}$., indicating a non-respiratory acidosis. This patient was scheduled for pneumonectomy and had the lowest $\mathrm{pH}$ of the entire group at every sampling period. The lowest $\mathrm{pH}$ occurred during sample period 9 (awake and breathing air) and was 7.25. At this time, the $\mathrm{Pa}_{\mathrm{CO}_{2}}$ was $32 \mathrm{~mm}$. $\mathrm{Hg}$ and the buffer-base value was $35 \mathrm{mEq}$. $/ \mathrm{L}$. The lowest buffer-base value occurred during sample periods 5 and 6 and was $33 \mathrm{mEq} . / \mathrm{L}$.

There was a tendency toward a mild respiratory alkalosis during sample periods 2 through 8.

While awake and breathing air, three of the patients had a $\mathrm{pH}$ less than 7.35 and all three had a buffer-base value of $45 \mathrm{mEq}$./L. or less. Only one of these three patients had an elevated $\mathrm{Pa}_{\mathrm{CO}_{2}}(46 \mathrm{~mm}$. $\mathrm{Hg}$ ). Four other patients had an elevated $\mathrm{Pa}_{\mathrm{CO}_{2}}$ (range 47 to $54 \mathrm{~mm}$. $\mathrm{Hg}$ ), but all had a normal $\mathrm{pH}$ (range 7.35 to 7.40 ). Their buffer-base values ranged from 47 to $51 \mathrm{mEq} . / \mathrm{L}$. 


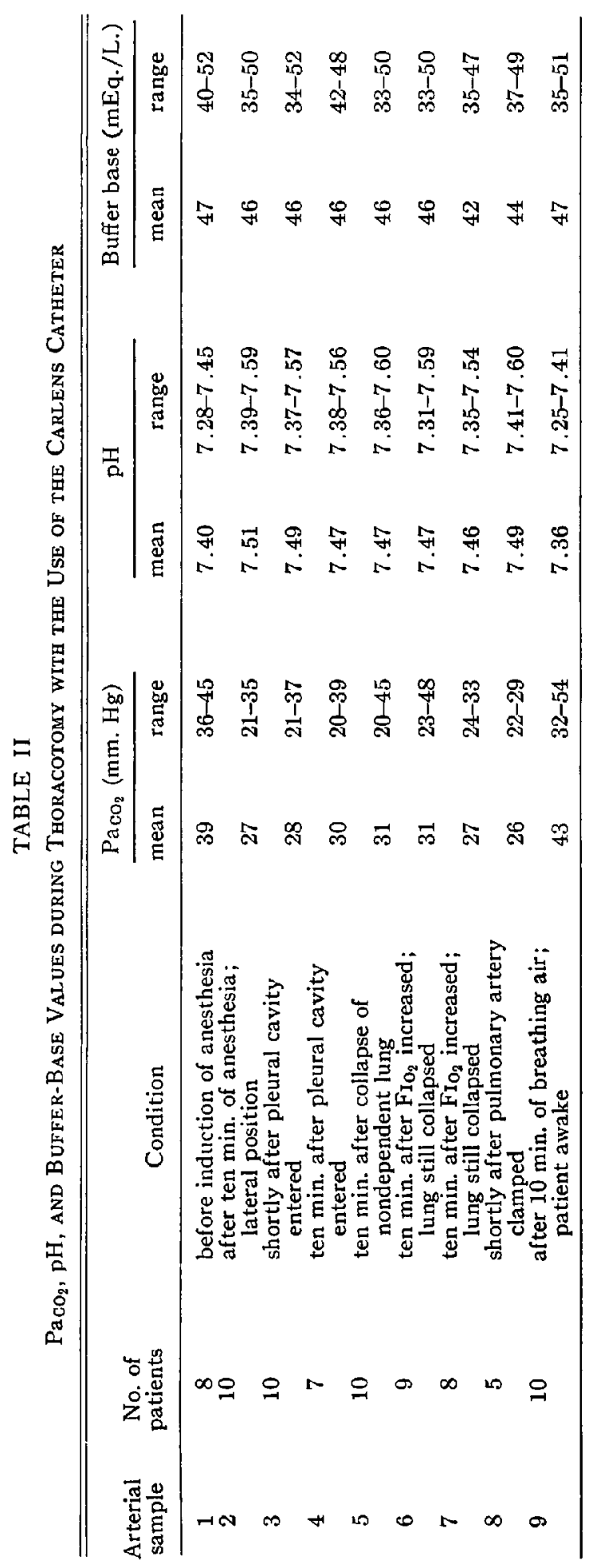




\section{Haematocrit}

Mean haematocrit values during sampling periods 1 through 9 were 44,38 , 40, $38,40,39,37,38$, and 42 per cent respectively.

\section{DisCUSSION}

\section{Oxygenation}

The presence of a low-normal or subnormal arterial $\mathrm{Po}_{2}$ in patients with lung disease, at rest, and particularly after premedication with narcotics, is not unexpected and is in agreement with the observations of others., ${ }^{2,6,12}$ Nine of the ten patients in this study had unilateral pulmonary disease. Even though the arterial oxygen tension is decreased, the degree indicates that only minimal cardiovascular compensatory mechanisms are required to ensure adequate oxygenation of tissue.

In the closed chest, lateral-positioned patient breathing 40 per cent oxygen, all $\mathrm{Pa}_{\mathrm{O}_{2}}$ levels were above normal. Under similar circumstances, Lunding and Fernandes ${ }^{7}$ demonstrated a mean $\mathrm{Pa}_{\mathrm{O}_{2}}$ of $98 \mathrm{~mm}$. $\mathrm{Hg}$ with 25 per cent oxygen and $163 \mathrm{~mm}$. Hg with 50 per cent oxygen. There were, however, patients with oxygen tensions as low as $60 \mathrm{~mm}$. $\mathrm{Hg}$ in the former group. We can conclude that, when a Carlens tube is used in a patient who is in a closed-chest lateral position, inspired oxygen concentrations of 40 to 50 per cent will ordinarily suffice.

When the pleural cavity was entered, the mean $\mathrm{Pa}_{\mathrm{O}_{2}}$ decreased from 161 to $135 \mathrm{~mm}$. Hg immediately and after ten minutes was $107 \mathrm{~mm}$. Hg. None of the $\mathrm{Pa}_{\mathrm{O}_{2}}$ values was less than $80 \mathrm{~mm}$. $\mathrm{Hg}$. Once the chest is opened, there is a variable degree of manipulation, retraction, and compression of the exposed lung. Presumably this produces a certain number of perfused but unventilated alveoli. This shunting of mixed venous blood will decrease the arterial $\mathrm{P}_{\mathrm{O}_{2}}$. Another mechanism of abnormal exchange of gas may be present in that some alveoli may be ventilated but unperfused. It is known that in the lateral position, there is a preferential pulmonary blood flow to the dependent lung..$^{13,14}$ The gradual, small increase in $\mathrm{Pa}_{\mathrm{CO}_{2}}$ during the open-chest periods is suggestive of an increasing dead space. Lunding and Fernandes ${ }^{7}$ also observed a decrease in $\mathrm{Pa}_{\mathrm{O}_{2}}$ in most patients when the chest was open, whether the patient was breathing 25,50 , or 100 per cent oxygen. Four of 15 patients in the group breathing 25 per cent oxygen had oxygen tensions less than $70 \mathrm{~mm}$. $\mathrm{Hg} 15$ minutes after the chest was opened. All their patients breathing 50 or 100 per cent oxygen had above normal values. Two of the three groups that had constant volume ventilation demonstrated an increase in $\mathrm{Pa}_{\mathrm{CO}_{2}}$ when the chest was opened, again suggestive of an increased dead space. Nilsson and associates ${ }^{5}$ reported a mean $\mathrm{Pa}_{\mathrm{O}_{2}}$ of $150 \mathrm{~mm}$. $\mathrm{Hg}$ when the patient breathed 50 per cent oxygen in this situation. Two of three patients breathing 33 per cent oxygen had values less than $72 \mathrm{~mm} . \mathrm{Hg}$, and all three patients receiving 25 per cent oxygen had levels less than $67 \mathrm{~mm}$. $\mathrm{Hg}$. Hallowell and associates, ${ }^{12}$ using a regular endotracheal tube and 50 per cent oxygen, demonstrated a mean $\mathrm{Pa}_{\mathrm{O}_{2}}$ of $88 \mathrm{~mm}$. $\mathrm{Hg}$ just prior to mitral valvotomy in 13 cases; however, in six cases the levels were $72 \mathrm{~mm}$. $\mathrm{Hg}$ or less. Virtue and co-workers, ${ }^{6}$ using 100 per cent oxygen and a Bonica-Hall ${ }^{15}$ endobronchial tube, studied 11 patients during thoracotomy. These patients demonstrated a slight but 
significant increase in the fraction of perfused but nonventilated alveoli and a greater increase in ventilated nonperfused alveoli after the chest was opened. These data indicate that the more important aetiologic factor probably is the increased dead space, with shunting a lesser factor. It would seem prudent to use oxygen concentrations of at least 40 per cent during this phase of thoracotomy in patients with unilateral lung disease. In the presence of bilateral lung disease, such as that accompanying mitral stenosis, higher concentrations may be necessary to ensure normal arterial oxygen tensions. ${ }^{8,12}$

After the intentional collapse of the nondependent lung, even 100 per cent oxygen may not provide adequate arterial oxygenation, in view of the two patients who had persistent low tensions ( 59 and $63 \mathrm{~mm}$. $\mathrm{Hg}$ ); alveolar ventilation was ample, as $\mathrm{Pa}_{\mathrm{CO}_{2}}$ equaled 33 and $23 \mathrm{~mm}$. $\mathrm{Hg}$, respectively.

In the presence of 100 per cent, the alveolar-arterial $\mathrm{Po}_{2}$ gradient $\left(\mathrm{A}-\mathrm{aDo} \mathrm{D}_{2}\right)$ is a reflection of the degree of mixed venous blood passing through nonventilated alveoli; that is, the larger the gradient, the greater the shunt. The gradients in the patients breathing 100 per cent oxygen during total lung collapse ranged from 352 to $597 \mathrm{~mm}$. Hg, indicative of a high degree of shunt. For example, an $\mathrm{A}-\mathrm{aDO}_{2}$ gradient of approximately $500 \mathrm{~mm}$. $\mathrm{Hg}$ would indicate a shunt of 30 per cent, or in other words, 30 per cent of the cardiac output was shunting through nonventilated alveoli. The percentage of shunting may be conveniently calculated from the shunt equation or, if the $\mathrm{Pa}_{\mathrm{O}_{2}}$ is at least $150 \mathrm{~mm}$. $\mathrm{Hg}$, by the modified shunt equation ${ }^{16}$ in which

$\dot{\mathrm{Q}}_{\mathrm{s}}=\frac{0.0031}{\left(\mathrm{Ca}_{\mathrm{O}_{2}}-\mathrm{C}_{\mathrm{O}_{2}}\right)} \frac{\left(\mathrm{A}-\mathrm{aDo}_{2}\right)}{+0.0031\left(\mathrm{~A}-\mathrm{aDo}_{2}\right)}$,

if it is assumed that the arterial-mixed venous oxygen content difference $\left(\mathrm{Ca}_{\mathrm{O}_{2}}-\mathrm{C}_{\mathrm{O}_{2}}^{-}\right)$is 6 volumes $/ 100 \mathrm{ml}$. Lunding and Fernandes found that all patients breathing 100 per cent oxygen had a $\mathrm{Pa}_{\mathrm{O}_{2}}$ of at least $85 \mathrm{~mm}$. $\mathrm{Hg}$ during total collapse. The mean $\mathrm{Pa}_{\mathrm{O}_{2}}$ was $121 \mathrm{~mm}$. $\mathrm{Hg}$, indicating a larger shunt than during partial collapse. They also demonstrated that 50 per cent oxygen during total collapse was not always sufficient. Nilsson and associates ${ }^{5}$ noted an increased $\mathrm{A}-\mathrm{aDO}_{2}$ gradient when the lung was collapsed, and they calculated shunts as high as 39 per cent. In 1953, Björk and co-workers ${ }^{4}$ reported decreases in arterial oxygen saturation of as much as 16 per cent during total collapse. Virtue and associates $^{6}$ reported a substantial increase in the fraction of nonventilated but perfused alveoli on occlusion of the bronchus. They concluded that the increased shunt that occurs after lung collapse was of no clinical significance because the arterial saturation was at least 96 per cent in all patients breathing 100 per cent oxygen. It is clear that when the lung is collapsed, 100 per cent oxygen should be used. It may be necessary to reinflate the exposed lung periodically if arterial desaturation occurs.

The reason for the significantly higher mean $\mathrm{Pa}_{\mathrm{O}_{2}}$ ten minutes after lung collapse in the patients undergoing lobectomy or pneumonectomy compared to those having a wedge resection of nonpulmonary surgery is obscure. One possibility is that in the former situation the surgeons collapse the lung more vigorously and therefore reduce pulmonary blood flow to a greater degree. 


\section{Effect of Hyperventilation}

Lunding and Fernandes ${ }^{7}$ made an interesting observation regarding carbon dioxide tensions. They noted that the patients who had the lowest $\mathrm{Pa}_{\mathrm{CO}_{2}}$ during closed-chest constant ventilation tended to have the greatest decreases in oxygen tension during total lung collapse. We have observed an obvious decrease in arterial saturation during left heart bypass using a Carlens tube when extremely vigorous ventilation was used and an apparent improvement when the minute ventilation was reduced. There is good evidence that high airway pressures can increase resistance to pulmonary blood flow. ${ }^{10}$ We suspect that during total collapse of one lung, increased airway pressures in the dependent lung may divert a greater proportion of the pulmonary blood flow to the collapsed lung and therefore decrease $\mathrm{Pa}_{\mathrm{O}_{2}}$. Because $\mathrm{Pa}_{\mathrm{CO}_{2}}$ is inversely proportional to the degree of alveolar ventilation, the $\mathrm{PaCO}_{2}-\mathrm{Pa}_{\mathrm{O}_{2}}$ relationship can be explored in graph form (Fig. 1) in which the arterial carbon dioxide and oxygen tensions during 100 per cent oxygen and total lung collapse are plotted. There is no apparent tendency

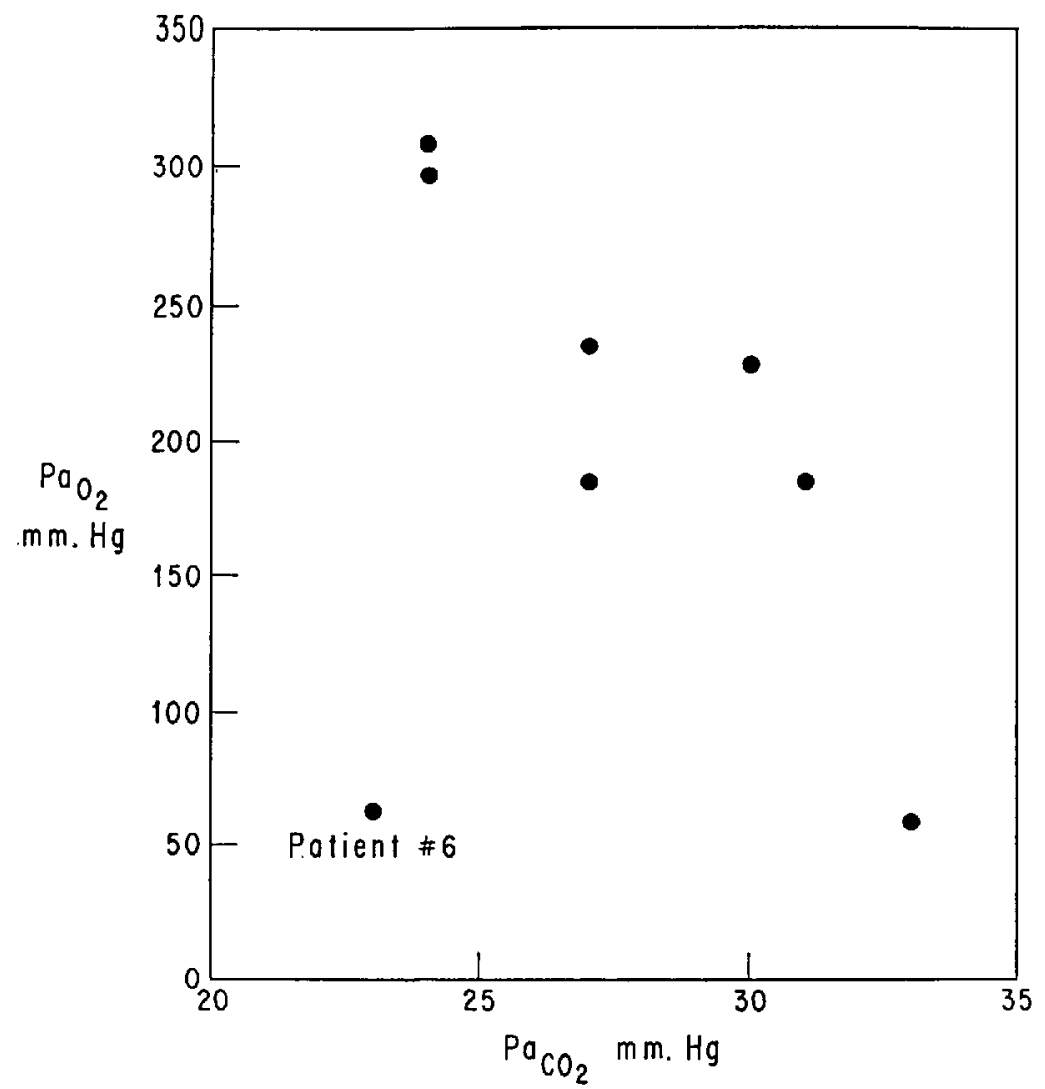

FIgure 1. Relationship of $\mathrm{Pa}_{\mathrm{CO}_{2}}$ to $\mathrm{Pa}_{\mathrm{O}_{2}}$ : eight patients with collapse of non-dependent lung, breathing 100 per cent oxygen. Note that as the degree of hyperventilation increased the $\mathrm{Pa}_{2}$ values tended to increase in all patients except patient 6 , in whom moderate hyperventilation was associated with a low $\mathrm{Pa}_{\mathrm{O}_{2}}$. 
for the more vigorously ventilated patients to have a lower $\mathrm{Pa}_{\mathrm{O}_{2}}$. In fact, of the three patients hyperventilated to a carbon dioxide tension less than $25 \mathrm{~mm} . \mathrm{Hg}$, two had the highest oxygen tensions. Only one patient (no. 6) had a subnormal $\mathrm{Pa}_{2}$ during hyperventilation. It cannot be said from this data that hyperventilation produces a greater shunt. We can only speculate that one patient had an exaggerated shunt in the nondependent lung that may have been related to the hyperventilation. More definitive work is needed to clarify this possible mechanism of increased shunting. When evaluating the $\mathrm{Pa}_{\mathrm{CO}_{2}}-\mathrm{Pa}_{\mathrm{O}_{2}}$ relationship, one must consider, as pointed out by Lunding and Fernandes, ${ }^{7}$ the effect of decreased $\mathrm{Pa}_{\mathrm{CO}_{2}}$ on alveolar oxygen tension (it tends to rise), and the displacement of the oxyhaemoglobin dissociation curve (which tends to decrease alveolar $\mathrm{Po}_{2}$ ).

\section{Clamping of the Pulmonary Artery}

If the pulmonary artery to the collapsed lung is clamped, the change in $\mathrm{A}-\mathrm{aDo}_{2}$ gradient will indicate the degree of shunting that was occurring in that lung. Before clamping, the $\mathrm{A}-\mathrm{aDo} \mathrm{O}_{2}$ gradient averaged $461 \mathrm{~mm}$. $\mathrm{Hg}$ (range from 352 to $597 \mathrm{~mm} . \mathrm{Hg}$ ) and after clamping, the gradient was $264 \mathrm{~mm}$. $\mathrm{Hg}$ (range from 181 to $438 \mathrm{~mm}$. $\mathrm{Hg}$ ). From the shunt equations, it is evident that an average of 27 per cent (range 16 to $62 \%$ ) of the cardiac output was being shunted prior to clamping. After clamping, the average shunt has decreased to 12 per cent (range 9 to $18 \%)$. This indicates that, before clamping, one half of the shunt was occurring in the collapsed lung and that one half was from the dependent ventilated lung. Nilsson and associates ${ }^{5}$ demonstrated ranges in shunts from 21 to 39 per cent during collapse of one lung. After clamping of the pulmonary artery in six patients, the $\mathrm{Pa}_{\mathrm{O}_{2}}$ increased in all from 20 to $300 \mathrm{~mm}$. $\mathrm{Hg}$. In two of these patients in Nilsson's study, five deep breaths were given after clamping and the $\mathrm{Pa}_{\mathrm{O}_{2}}$ increased from 488 to $578 \mathrm{~mm}$. $\mathrm{Hg}$ in one patient and from 292 to $624 \mathrm{~mm}$. $\mathrm{Hg}$ in the other. This indicates a large partly reversible shunt had been present in the dependent lung. Newman and associates ${ }^{2}$ demonstrated an increase of 6 per cent in arterial saturation in dogs after clamping. Björk and co-workers ${ }^{4}$ noted that the "[arterial] oxygen saturation returns to the normal level as soon as the pulmonary artery is ligated." It seems reasonable to encourage early ligation of the pulmonary artery during pneumonectomy.

\section{Postoperative}

The oxygen and carbon dioxide tensions during the breathing of air after surgery indicate that arterial desaturation is probably due to a combination of venous admixture and alveolar hypoventilation. There was no significant difference between oxygen tensions in the patients with pneumonectomy and those in patients undergoing other procedures. It is obvious that in these patients, high concentrations of oxygen must be breathed during the postoperative course. Efforts to improve alveolar hypoventilation and to decrease shunting may be indicated.

\section{Acid-Base}

The respiratory alkalosis present in this study was intentional, as ventilation was altered as necessary to prevent retention of carbon dioxide. Only brief periods 
of minimal retention of carbon dioxide occurred. There was no indication of a non-respiratory acidosis developing, as the buffer-base value was unchanged except for an insignificant ( $p>0.8$ ) decrease from $46 \mathrm{mEq} . / \mathrm{L}$. during sample period 6 to $42 \mathrm{mEq}$./L. during sample period 7. There was no correlation between individual buffer-base values and oxygen tensions less than $70 \mathrm{~mm}$. $\mathrm{Hg}$. This is contrary to the findings of Lunding and Fernandes, ${ }^{7}$ who noted that a slight decrease was greatest in patients with oxygen tensions less than $60 \mathrm{~mm}$. Hg. After the operation, five of ten patients had mild retention of carbon dioxide, as much as $54 \mathrm{~mm}$. $\mathrm{Hg}$.

\section{SUMMARY}

Blood gas and $\mathrm{pH}$ measurements were made in ten patients during thoracotomy using a Carlens endobronchial catheter. Arterial oxygenation is usually adequate if (1) high concentrations of oxygen are used, (2) the pulmonary artery is ligated as soon as possible during pneumonectomy, and (3) atelectasis in the dependent lung is prevented by vigorous ventilation. Acidosis is unlikely to occur.

\section{RÉSUMÉ}

Nous avons fait, chez dix malades subissant une thoracotomie sous intubation bronchique avec le tube Carlens, des études du $\mathrm{pH}$ et des gaz du sang artériel. Le taux d’oxygène dans le sang artériel est adéquat à la condition (1) d'employer de hautes concentrations d'oxygène, $(2)$ de ligaturer l'artère pulmonaire aussitôt que possible au cours de la pneumonectomie, (3) de prévenir l'atélectasie dans le poumon en déclivité en assurant une ventilation vigoureuse. Selon toute vraisemblance, il ne se produit pas d'acidose.

\section{REFERENCES}

1. Björk, V. O. \& Carlens, E. The Prevention of Spread during Pulmonary Resection by the Use of a Double-Lumen Catheter. J. Thorac. Cardiov. Surg. 20: 151 (1950).

2. Newaman, R. W.; Finer, G. E.; \& Downs, J. E. Routine Use of the Carlens DoubleLumen Endobronchial Catheter. J. Thorac. Cardiov. Surg. 42: 327 (1961).

3. Jenkins, A. Vivian \& Clarke, G. Endobronchial Anaesthesia with the Carlens Catheter. Brit. J. Anaesth. 30: 13 (1958),

4. Björk, V. O.; Carlens, E.; \& Friberg, O. Endobronchial Anesthesia. Anesthesiology. 14: 60 (1953)

5. Nllsson, E.; Slater, E. M.; \& Greenberg, J. The Cost of the Quiet Lung: Fluctuations in $\mathrm{Pa}_{\mathrm{O}_{2}}$ When the Carlens Tube Is Used in Pulmonary Surgery. Acta anaesth. scandinav. 9: 49 (1965).

6. Virtue, R. W.; Permutt, S.; Tanaka, R.; Pearcy, C.; Bane, H. N.; \& BhombergerBarneA, B. Ventilation-Perfusion Changes during Thoracotomy. Anesthesiology. 27: 132 (1966).

7. Lunding, M. \& Fernandes, A. Arterial Oxygen Tension and Acid-Base Status during Thoracic Anaesthesia: With Special Reference to the Effect of Total Collapse of One Lung as Obtained by Using Double-Lumen Tubes. Acta anaesth. scandinav. 11: 43 (1967).

8. Bonica, J. J.; Green, H. D.; Takamura, J. H.; Goodson, D. N.; Ziegler, T. Q.; \& WILson, J. F. Factors Which Affect Ventilatory Function during Surgical Pneumothorax. J.A.M.A. 180: 185 (1962).

9. Edwards, E. M. \& Hatch, D. J. Experiences with Double-Lumen Tubes. Anaesthesia, 20:461 (1965). 
10. Andersen, M. N. \& Kuchiba, K. Depression of Cardiac Output with Mechanical Ventilation: Comparative Studies of Intermittent Positive, Positive-Negative, and Assisted Ventilation. J. Thorac. Cardiov. Surg. 54: 182 (1967).

11. Sincer, R. B. \& Hastrncs, A. B. An Improved Clinical Method for the Estimation of Disturbances of Acid-Base Balance of Human Blood. Medicine (Balt). 27: 223 (1948).

12. Halloweld, P.; Hedley-Whyte, J.; Austen, W. G.; \& Laver, M. B. Oxygenation during Closed Mitral Valvulotomy. J. Thorac. Cardiov. Surg. 50:42 (1965).

13. Rothstein, E.; Landis, F. B.; \& Narodick, B. G. Bronchospirometry in the Lateral Decubitus Position. J. Thorac. Cardiov. Surg. 19: 821 (1950).

14. Svanberg, L. Influence of Posture on the Lung Volumes, Ventilation and Circulation in Normals: A Spirometric-Broncospirometric Investigation. Scandinav. J. Clin. Lab. Invest. 9 (Suppl. 25): 1 (1957).

15. BonICA, J. J. \& HALl, W. M. Endobronchial Anesthesia for Intrathoracic Surgery. Anesthesiology. 12: 344 (1951).

16. Laver, M. B. \& SEIfEN, A. Measurement of Blood Oxygen Tension in Anesthesia. Anesthesiology. 26: 73 (1965). 